\title{
Dr. Shivaji Sircar: the Air Products years (1973-2001)
}

\author{
Timothy C. Golden ${ }^{1}$
}

Received: 18 January 2021 / Revised: 19 January 2021 / Accepted: 19 January 2021 / Published online: 8 February 2021

(c) The Author(s), under exclusive licence to Springer Science+Business Media, LLC part of Springer Nature 2021

\section{Dr. Shivaji Sircar, (Photo courtesy of the Sircar family)}

My friend and mentor Dr. Shivaji Sircar passed away on 13 February 2020. What follows are some of my impressions and recollections from working with him for $20+$ years during his tenure at Air Products and Chemicals, Inc.

Shivaji received his B.S in chemical engineering from Jadavpur University, India in 1964. He worked for a year as a research fellow at the Central Fuel Research Institute in India, and then he got his M.S. (1968) and Ph.D (1970) in chemical engineering from the University of Pennsylvania, Philadelphia. His Ph.D was done under the direction of Professor Alan Myers so his adsorption roots run deep. He was a post- doctoral fellow at the same university for two years and then joined Air Products and Chemicals, Inc., Allentown, PA, in 1973.

\section{Shivaji the new hire}

When Shivaji was hired at Air Products and Chemicals, Inc in 1973, he was essentially Air Products' first employee in the adsorption area. His primary task was to start, build and grow the adsorption capabilities of the company. Shivaji began his task by building laboratory devices to better understand the fundamentals of adsorption. He understood clearly that any viable adsorption process had to have a good fundamental basis. If he was going to build a house, he was going to build it on a strong foundation. Several years were spent generating databooks full of fundamental data that are still in use today. Only after the database was sufficiently complete with fundamental data did the R\&D efforts move to building large scale pilot units with emphasis on collecting process data for plant designs.

Timothy C. Golden

GOLDENTC@airproducts.com

1 Air Products and Chemicals, Inc, Allentown, PA 18195, USA

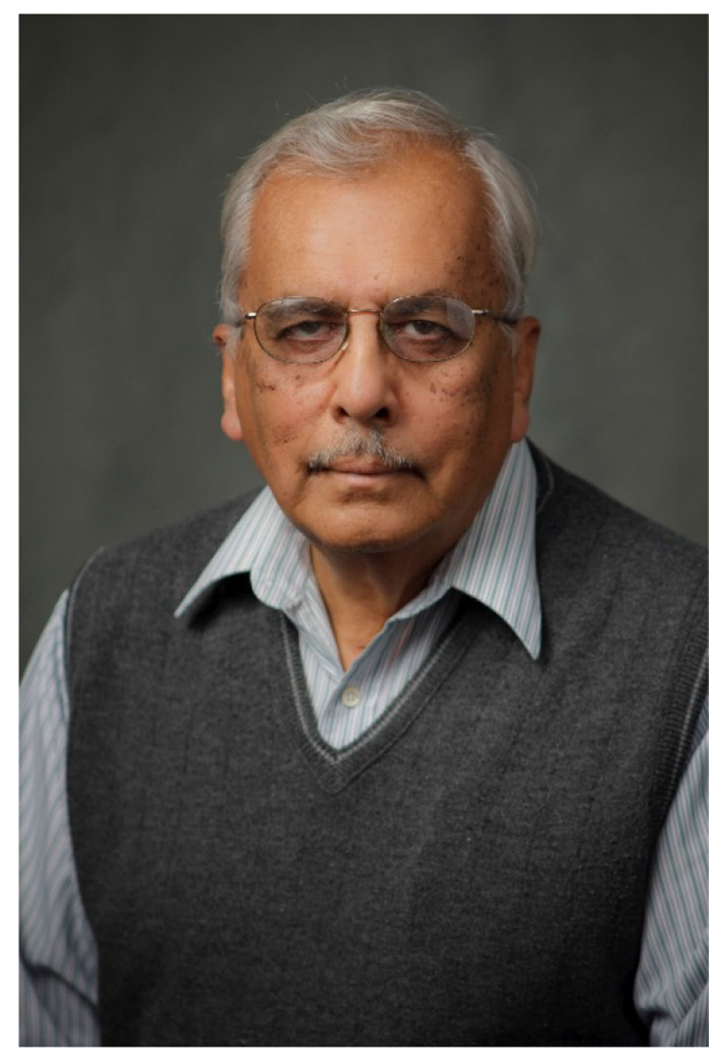

Initially, Shivaji encountered a lot of institutional resistance from the engineering community at Air Products. It was early days for adsorption technology and there were many skeptics. Despite the groundbreaking work of Professor Richard Barrer and the amazing things that Union Carbide was doing in both adsorbent materials and adsorption processes the late 1960 's, there was still significant doubt in the engineering community that a semi-batch separation process with faulty switch valves would ever become commercially viable. He had to use all his skills as an advocate, teacher, fighter, diplomat, and prophet in addition to his substantial technical acumen to advance the technology and overcome the skeptics. Fast forward 50 years and 
every product that an industrial gas company sells uses the unit operation of adsorption somewhere in its production. The adsorption technology platform originally initiated by Shivaji is alive and well at Air Products and continues to develop new products for new and old markets. And his legacy is indelibly woven into the fabric of adsorption technology at Air Products.

\section{Shivaji the inventor}

Shivaji's first commercial product was a device to produce $\mathrm{N}_{2}$ from ambient air in 1980 [21]. The technology helped launch the concept of gas generators. Rather than separate air cryogenically miles away and truck in liquid on a regular basis, a gas generator could use ambient air and an on-site device to produce the desired product. Gas generators are now a standard in the industry suppling $\mathrm{N}_{2}, \mathrm{O}_{2}$ and $\mathrm{H}_{2}$ to customers in a more sustainable fashion. At the heart of all these gas generators is an adsorption-based separation device. The technology, termed $\mathrm{N}_{2}$ VSA, was one of the first adsorption processes to use vacuum to regenerate the adsorbent and produce a pure product at low pressure. The process also included a rinse step to ensure high purity of the evacuated $\mathrm{N}_{2}$ product. The process was also capable of producing both $\mathrm{O}_{2}$ and $\mathrm{N}_{2}$ if desired. This cycle with a rinse step and a strongly adsorbing vacuum product was essentially the basis for Shivaji's Gemini processes (adsorption process to form two pure products).

The Gemini- 5 process ( 5 for a 5 bed process) for separation of landfill gas into both pure $\mathrm{CO}_{2}$ and $\mathrm{CH}_{4}$ at high recovery $[16,25]$ was developed soon after the $\mathrm{N}_{2}$ VSA. This
VSA process used $13 \mathrm{X}$ as the adsorbent with high selectivity for $\mathrm{CO}_{2} / \mathrm{CH}_{4}$. The weakly adsorbed $\mathrm{CH}_{4}$ was produced at purity sufficient $(98+\%)$ for direct injection to a pipeline and at high pressure. A high purity $\mathrm{CO}_{2}$ stream $(98+\%)$ was also be produced under vacuum after a high-pressure rinse step. A portion of this recovered $\mathrm{CO}_{2}$ was used as regeneration gas for an upstream TSA employed to remove heavy hydrocarbons and other impurities from the raw LFG which would foul the 13X. Several plants using this technology were built in the later 1980's. Many aspects of this concept are commercially employed to produce pipeline-grade natural gas from biogas and other $\mathrm{CH}_{4}$-rich gas sources today.

Gemini-9 was Shivaji's final foray into the two pure product adsorption-based process $[17,20]$. This was a 9 bed VSA/PSA process that allowed production of both pure $\mathrm{CO}_{2}$ and $\mathrm{H}_{2}$ from synthesis gas. The concept was commercialized at the Air Products Butler, PA plant in 1993 and continues to run today. Interest in this type of technology has been heightened given the need for capture, utilization, and storage of carbon. Using the basics of Shivaji's initial Gemini concept, Air Products has built $\mathrm{CO}_{2}$ VSA's on two large $\mathrm{H}_{2}$ PSA's in Port Arthur, Texas. Figure 1 shows an aerial photo of the one of the Air Products' Port Arthur plants showing the retrofitted $\mathrm{CO}_{2}$ VSA's and one of the original $\mathrm{H}_{2}$ PSA's and reformer. The two VSA's have been capturing about 2500 tons $\mathrm{CO}_{2}$ /day since 2014. The captured $\mathrm{CO}_{2}$ is delivered to a pipeline and used for enhanced oil recovery. Shivaji's patent from 1988 is a possible template for large-scale $\mathrm{H}_{2}$ production and capture-ready $\mathrm{CO}_{2}$ in the future where the economics favor an adsorption approach vs an amine scrubber (value of electricity vs steam) for $\mathrm{CO}_{2}$

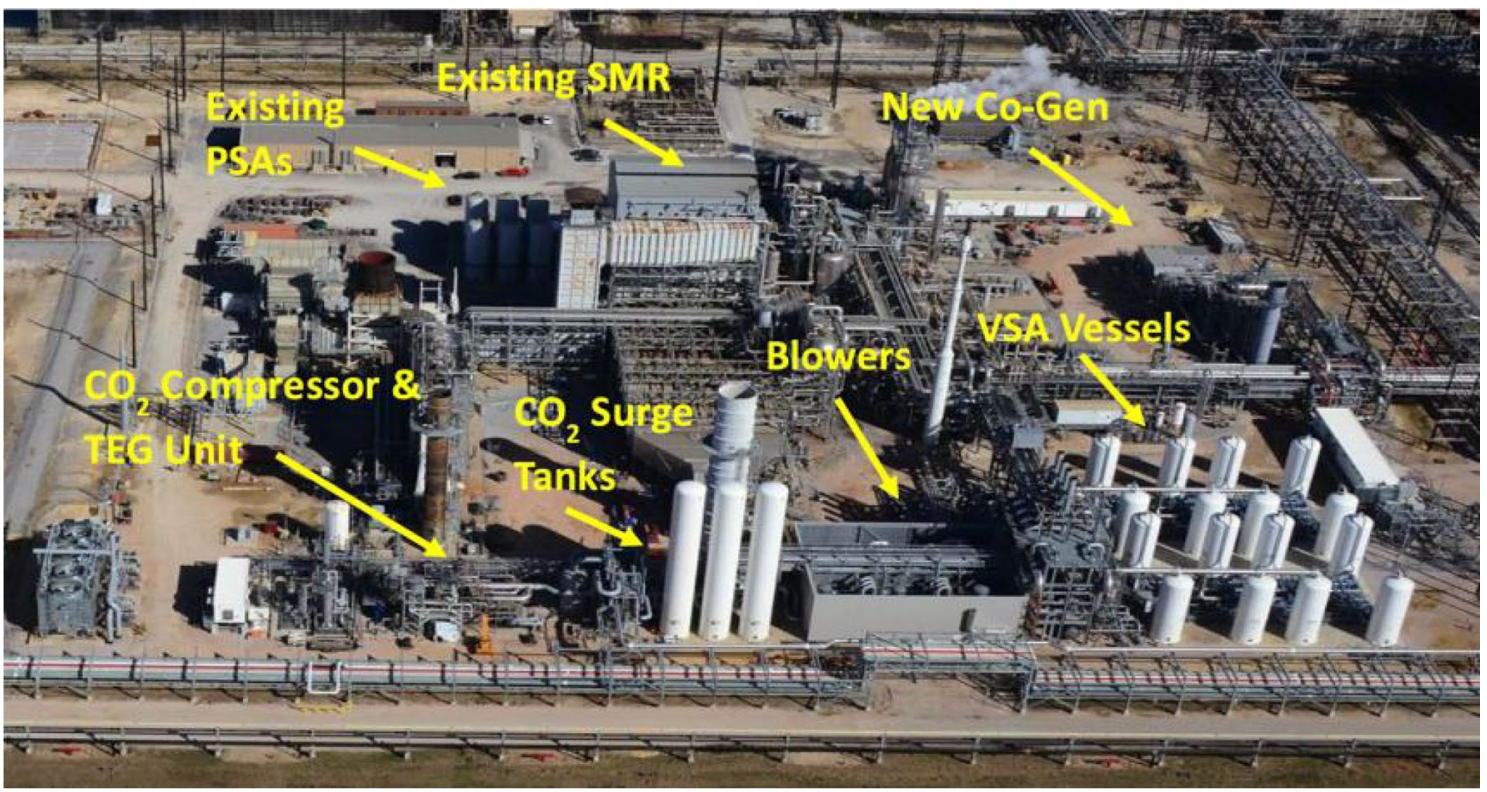

Fig. 1 Simultaneous $\mathrm{H}_{2}$ and $\mathrm{CO}_{2}$ Production at Air Products Port Arthur facility (photo courtesy of Air Products and Chemicals, Inc) 
capture. It combines simultaneous $\mathrm{H}_{2}$ production and $\mathrm{CO}_{2}$ capture, utilization, and storage. Since $\mathrm{H}_{2}$ production contributes about $0.2 \%$ of the worldwide $\mathrm{CO}_{2}$ emissions this is not an insignificant fraction of total worldwide emissions. This work was also the foundation to Air Products' $\mathrm{H}_{2}$ PSA product-line and the company's strong position in the sale of gas $\mathrm{H}_{2}$ business which constitutes a significant fraction of Air Products' total revenue.

\section{Shivaji the scientist}

In the early 1990's the corporation decided that given Shivaji's creativity he was well suited for more exploratory, higher risk projects. Thus, he took an assignment in our Corporate Science Center to develop new concepts and technologies. The first concept he explored was selective surface flow (SSF) membranes which was a concept first illustrated by one of his heroes and Air Products consultant Professor Barrer. Shivaji and his team succeeded in producing nanoporous membranes which selectively permeated larger molecules via selective adsorption, pore blockage and surface flow [9, 10]. The rather simple fabrication was achieved by applying a PVDC latex on a porous alumina support and then carbonizing. This resulted in a nanoporous carbon layer on a macroporous support. Of primary interest to Air Products was that the small, weakly adsorbed molecules (like $\mathrm{H}_{2}$ and He which are significant revenue generators for an industrial gas company) remained at high pressure unlike polymer membranes. The resultant high pressure of the small, weakly adsorbing molecule removes the need for compression for further purification or use. Figure 2 shows a picture of the SSF commercial demonstration unit for recovery of C2-C6 hydrocarbons and $\mathrm{H}_{2}$ from a refinery off-gas stream [22].

Shivaji's Ph.D thesis was on the thermodynamics of adsorption at the liquid-solid interface and the separation and purification of liquids by adsorption was always near and dear to his heart. In the early 1990's, Shivaji and his team developed several liquid separation processes which he termed concentration swing adsorption [18]. The processes developed included the production of motor fuel grade ethanol [19] and processes to break azeotropes [2].

Another area of his research during this period was hybrid systems which combined reaction and sorption (sorption enhanced reaction or SER). Processes developed included the production of pure CO by SER in the reverse shift reaction [7], sorption enhanced $\mathrm{H}_{2}$ production during steam methane reforming $[6,23]$ and sorption enhanced water gas shift reaction which allows the production of $\mathrm{H}_{2}$ without the need for a final PSA purification step [1].

The cornerstone of this work was finding a material that would reversibly adsorb $\mathrm{CO}_{2}$ even in the presence of steam

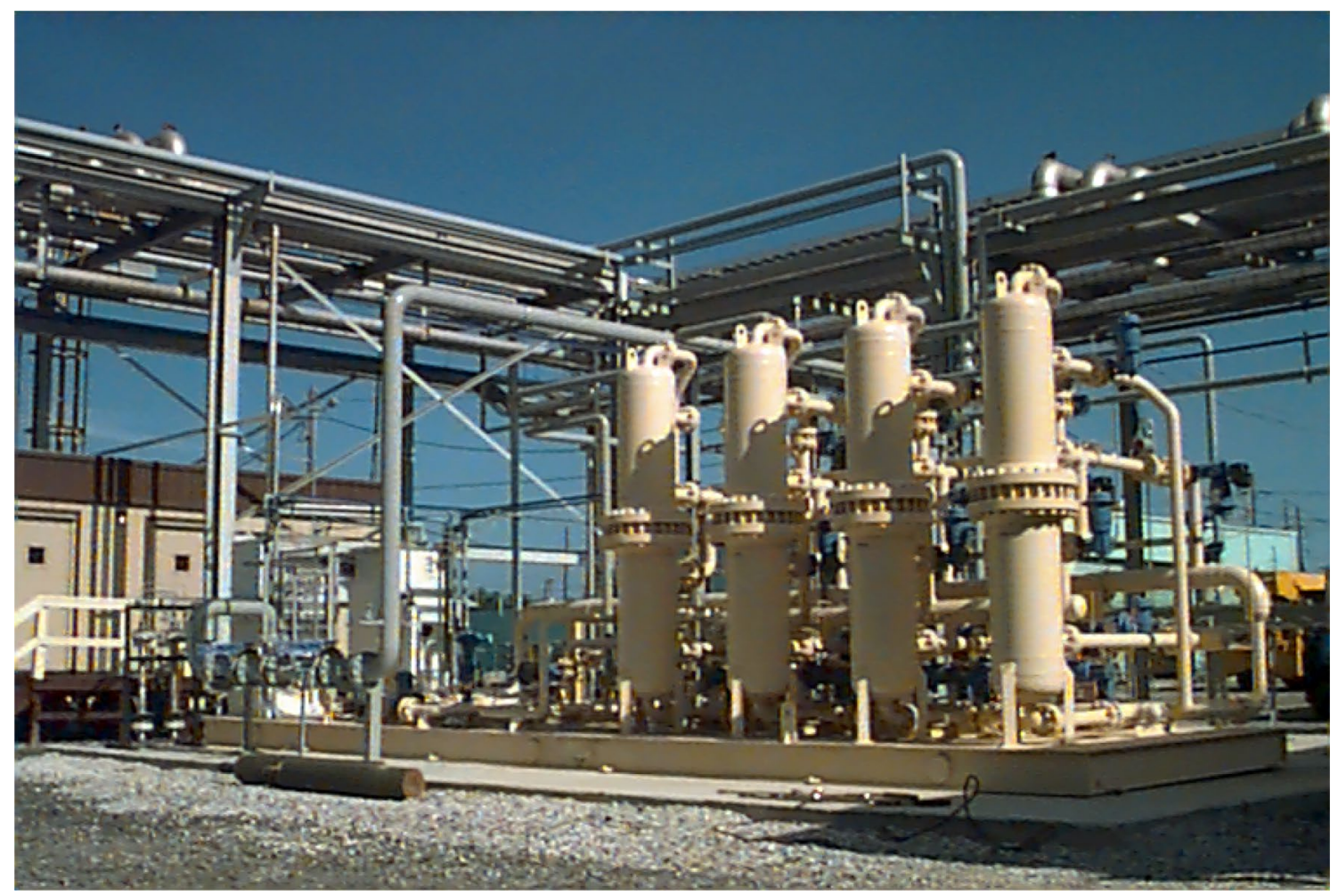

Fig. 2 SSF membrane commercial demonstration plant [22] 
at temperatures of $250{ }^{\circ} \mathrm{C}$ and above [6]. With today's current emphasis on process intensification and carbon capture, utilization and storage others have continued to develop the SER concept. A paper on the status of the technology development nearing commercialization are presented in this issue of the journal.

Adsorption is a daunting field of study. Often the technology outpaces the science. So, for example, despite failure to totally understand the complexities of multicomponent equilibrium and mass transfer we continue to build separation devices which work (grace of pilot scale experiments) and perform a given separation more cheaply and with less energy than the next best alternative. Yet the advances in adsorption science have increased dramatically over the last 30 years and Shivaji has been one of the leaders in that area as well. During his career he published and presented over 200 papers in addition to receiving 60 US patents. His research publications covered a wide range of subjects including adsorption thermodynamics and mass transfer $[13,15]$, adsorbent heterogeneity [14], chemisorption [8], process development [24], mathematical modeling [5, 26], materials development [4] and characterization related to surface phenomenon and adsorption both at the fundamental and applied levels [11]. A true Renaissance man in the adsorption world.

\section{Shivaji the experimentalist}

Shivaji was also keenly interested in developing techniques to better determine fundamental properties of adsorption. One elegant technique he developed was an isotope exchange technique for measurement of multicomponent adsorption equilibria and mass transfer [12]. The beauty of this technique is that mass transfer properties could be measured without any heat effects. He also developed a multicomponent differential calorimeter for measurement of heats of adsorption [3]. These devices are used to better understand adsorption fundamentals and help derive improved equilibrium and mass transfer models required for accurate process simulations.

\section{Shivaji the mentor}

One key attribute of Shivaji's was his passion about adsorption science and technology and those who worked with him were instilled with that same passion. He was an old-school mentor: demanding, tough, stubborn, but fair. Working with Shivaji was sometimes a bumpy road, but the destination was worth it. He spent time teaching, defining the technical problem and possible solutions before letting you hit the lab. While he demanded hard work, he set the example with his prodigious work ethic. Throughout his Air Products career, he averaged about 5 publications and 2 patents per year. While those of us on Shivaji's team didn't always agree with him all the time we all had respect for his technical acumen, his work ethic, and his unwavering desire to teach.

One life event clearly showed Shivaji's tenacious character. In the late 1990's, he had open heart surgery. While the surgery went well, he had an allergic reaction to the anesthesia which left him in a coma. In typical Shivaji fashion, he fought and to the surprise of many he awoke after a 3-month slumber. As soon as he gained back some strength, all his direct reports would have meetings in his living room, and he would inquire about the status of the programs like he was asking about his babies. After the coma, his lungs were very compromised and ironically, he was never far from his adsorption-based home medical $\mathrm{O}_{2}$ generator.

\section{Shivaji the honoree}

Given the depth and breadth of Shivaji's work, he received numerous honors and was very active in the adsorption community. He was elected programming chairman of AIChE Adsorption and Ion-Exchange Committee (1992-93), was elected co-chairman of International Conference on Fundamentals of Adsorption in Japan (1992), was a member of AIChE Award Committee (1992-96), was a treasurer (1993) and a Director of International Adsorption Society (1995-97). He was a member of the advisory boards of four technical journals: Adsorption, Adsorption Science and Technology, Indian Chemical Engineering, and Industrial and Engineering Chemistry Research (00-02).

He was honored by AIChE with the Professional Progress Award (1988) and with the Industrial Gases Technology Award (2001) for his technical contributions in the field of Adsorption Science and Technology. A session in adsorption was dedicated to honor him at the annual AIChE meeting in 2001. A special issue of the journal "Adsorption" was dedicated to honor him in 2003. He was bestowed with the 2004 DOST Professor S. K. Sharma Medal and the Chemcon Distinguished Speaker Award by the Indian Institute of Chemical Engineers. He was elected to be a member of the National Academy of Engineering (NAE) in 2004 and inducted to be a Fellow of the International Adsorption Society in 2013.

\section{Shivaji the person}

A person's life is not defined by what they do, but who they are. Shivaji was a multi-faceted person with a wide range of interests and hobbies. Firstly, he was a voracious reader. He could speak comfortably about all types of science and 
technology. But he was also extremely knowledgeable about history, religion, sports, and politics. He would often come to my office after lunch and talk for $30 \mathrm{~min}$ about any variety of subjects before telling me I had to get my experiments done more quickly. And whenever he sat down, you never knew where the conversation would lead. But it was always enlightening, engaging, and entertaining.

Shivaji was also an avid traveler. He left no part of the globe unexplored. And whenever he traveled, his camera was in tow. Having a look at Shivaji's photography portfolio was a real pleasure. Ever the perfectionist, he would determine when the light would be the best before taking his photos often waking poor Shukla, his wife, in the early morning hours. Typical Shivaji; anything worth doing was worth doing well.

He enjoyed sports and was a more than adequate tennis player. On more than one occasion he soundly thrashed me despite being 10 years his junior. Ever the gentleman, he refused to rub it in unless I failed to pay for the post-match beverages.

Shivaji was a wonderful teacher and he would share his knowledge like he was giving away gifts. To me, this was his greatest attribute. In his impromptu discourses, he would march up to the white board and start at one end with very fundamental equations. After filling two boards filled with equations, diagrams, plots he would have connected the fundamental with the applied, the microscopic with the macroscopic. Making this complicated technology we all study a bit more illuminated. At the request of many employees who had witnessed his engaging performances, Shivaji eventually put an internal course together on adsorption that was attended by scientists, engineers, and operations personnel throughout the corporation. It always played to a full house of eager students. Thus, a new legion of adsorption scientists was enabled. Rest in peace Shivaji.

\section{References}

1. Beaver, M.G., Caram, H.S., Sircar, S.: Selection of $\mathrm{CO}_{2}$ chemisorbent for fuel-cell grade $\mathrm{H}_{2}$ production by sorption-enhanced water gas shift reaction . Int. J. Hydrogen Energy 34, 2972-2978 (2009)

2. Chen, M.S.K., Sircar, S.: Process for preparing alkyl tert-alkyl ethers, US patent 5,030,768, 9 July 1991

3. Dunne, J., Rao, M.B., Sircar, S., Gorte, R.J., Myers, A.L.: Calorimetric heats of adsorption and adsorption isotherms: mixtures of $\mathrm{CH}_{4}$ and $\mathrm{C}_{2} \mathrm{H}_{6}$ in silicalite and mixtures of $\mathrm{CO}_{2}$ and $\mathrm{C}_{2} \mathrm{H}_{6}$ in NaX. Langmuir 13, 4333 (1997)

4. Golden, T.C., Sircar, S.: Activated carbon adsorbent for drying gases by pressure swing adsorption. Carbon 28, 683 (1990)
5. Hartzog, D.G., Sircar, S.: Sensitivity of PSA process performance to input variables. Adsorption 1, 133 (1995)

6. Hufton, J.R., Mayorga, S., Sircar, S.: Sorption enhanced reaction process for hydrogen production. AIChE J. 45, 248 (1999)

7. Hufton, J.R., Sircar, S., Baade, W.F., Abrardo, J.M. and Anand, M.: Integrated steam methane reforming process for producing carbon monoxide, US patent 6,328,945, 11 Dec 2001

8. Lee, K.B., Beaver, M.G., Caram, H.S., Sircar, S.: Reversible chemisorption of $\mathrm{CO}_{2}$ and their potential applications. Ind. Eng. Chem. Res. 47, 8048-8062 (2008)

9. Rao, M.B., Sircar, S., Golden, T.C.: Gas separation by adsorbent membranes, US patent 5,104,425, 14 April 1992

10. Rao, M.B., Sircar, S.: Nanoporous carbon membrane for gas separation. Gas Sep. Purif. 7, 279 (1993)

11. Rao, M.B., Sircar, S.: Performance and pore characterization of nanoporous carbon membranes for gas separation. J. Membr. Sci. 110, 109 (1996)

12. Rynders, R.M., Rao, M.B., Sircar, S.: Isotope exchange technique for measurement of pure and multicomponent gas adsorption equilibria and kinetics. AIChE J. 43, 2456 (1997)

13. Sircar, S.: Linear-driving-force model for non-isothermal gas adsorption kinetics. J. Chem. Soc. Faraday Trans. I. 79, 785 (1983)

14. Sircar, S.: Adsorption of gases on heterogeneous adsorbents. J. Chem. Soc. Faraday Trans. I. 80, 1101 (1984)

15. Sircar, S.: Excess properties and thermodynamics of multicomponent gas adsorption. J. Chem. Soc. Faraday Trans. I. 81, 1527 (1985)

16. Sircar, S.: Separation of methane and carbon dioxide gas mixtures by pressure swing adsorption. Sep. Sci. Technol. 23(6 \& 7), 519 (1988a)

17. Sircar, S.: Fractionation of multicomponent gas mixture by pressure swing adsorption, US patent 4,790,858, 13 Dec 1988b

18. Sircar, S.: Separation of liquid mixtures by concentration swing adsorption, US patent 5,026,482, 25 June 1991a

19. Sircar, S.: Process for preparing motor fuel grade alcohol, US patent 5,030,775, 9 July $1991 \mathrm{~b}$

20. Sircar, S., Kratz, W.C.: Simultaneous production of hydrogen and carbon dioxide from steam reformer off-gas by pressure swing adsorption. Sep. Sci. Technol. 23(14 \& 15), 1397 (1988)

21. Sircar, S. and White, T.R.: Vacuum swing adsorption for air fractionation, US patent 4,264,340, 28 April 1981

22. Sircar, S., Rao, M.B., Thaeron, C.M.A.: Selective surface flow membrane for gas separation. Sep. Sci. Technol. 34(10), 2081 (1999)

23. Sircar, S., Hufton, J.R. and Nataraj, S.: Process and apparatus for the production of hydrogen by steam reforming of hydrocarbons, US patent 6,103,143, 15 Aug 2000

24. Sircar, S., Rao, M.B., Golden, T.C.: Fractionation of air by zeolites. In: Dabrowski, A. (ed.) Adsorption and its Application in Industry and Environmental Protection, pp. 395-423. Elsevier, The Netherlands (1999)

25. Sircar, S., Kumar, R., Koch, W.R. and VanSloun, J.: Recovery of methane from landfill gas, US patent 4,770,676, 13 Sept 1988

26. Waldron, W.E., Sircar, S.: Parametric study of a pressure swing adsorption process. Adsorption 6, 179 (2000)

Publisher's Note Springer Nature remains neutral with regard to jurisdictional claims in published maps and institutional affiliations. 